\title{
Homenaje: Este fue un Hombre (Palabras de Despedida a Juan de Castro Reyes)
}

\author{
Ricardo Rosas
}

La editora de la Revista me ha pedido escribir unas líneas de despedida a nuestro querido amigo, colega y decano Juan de Castro Reyes, fallecido hace algunos meses. Me he sentido muy honrado del encargo, por la gran humanidad del personaje que estamos despidiendo. Pero también me he sentido muy perturbado, por no acertar, en varios meses, a dar con el tono de estas palabras. En una revista científica, tal vez se esperaba que hiciera un análisis más o menos sesudo de su vasta obra escrita, principalmente en temas de Psicología de la Religión, Jung y el Eneagrama. Pero he de reconocer que, a pesar de haber leído dos de sus libros, no me siento para nada calificado en estos temas. O tal vez el hilo conductor debía ser el de su reconocido aporte al país en tiempos durísimos de la dictadura, cuando le tocó dirigir la Vicaría de la Solidaridad. Pero yo lo conocí varios años después, ya en los albores del retorno a la democracia. Además, me pasé todos los años de su gestión en el extranjero. O tal vez debiera haberme concentrado en su rol de decano de la Facultad de Ciencias Sociales, donde gracias a su decidido compromiso, la Escuela de Psicología de la Universidad Católica comenzara la senda que la tiene hoy en un estado de desarrollo comparable a las grandes del orbe. Pero creo que ello haría de estas palabras un asunto demasiado local. Así las cosas, y después de decirle a la editora que la tarea me estaba sobrepasando, me respondió algo muy sencillo: céntrate en la persona, no en su obra.

Y así, recordé las largas horas compartidas con Juan mientras fue decano de la Facultad, y la tarea que al principio me pareció tan difícil, comenzó a hacerse transparente.

Juan de Castro fue un hombre como el que describe Primo Levi, en su libro Esto es un Hombre: íntegro, sencillo, humano, servicial, humilde, firme, flexible y cariñoso. Sus amigos le decían Juan. Los no tanto, paradojalmente, "el cura". El trataba a todos por igual. Su sonrisa rompía los hielos más duros. Dotado de un natural instinto, ayudado por su paso por la diplomacia vaticana, resolvía difíciles conflictos políticos con una sencillez pasmosa. Nunca le interesó el poder, pero cuando lo detentó, lo hizo con maestría. Su principal característica como jefe fue la conformación de equipos de trabajo con proyectos autónomos, que él estimulaba permanentemente. Le gustaba delegar, y apoyaba firmemente a sus equipos. Como para él lo principal siempre fueron las personas, se preocupaba y esmeraba por inventar muchas ocasiones de encuentro social en las que se generaban fuertes lazos de amistad y compromiso con el proyecto común. En nuestro caso, no era infrecuente quedarse hasta la madrugada afinando algún proyecto de reforma que debíamos presentar a las entonces escépticas autoridades de la Universidad. Estuvo, asimismo, siempre preocupado del bienestar de las personas que trabajaban en su entorno, especialmente de los más vulnerables. Sabía llegar a todos, acompañando en momentos de dificultad, y apoyando cuando era necesario. Cuando nos dejó, surgieron innumerables relatos de personas que recibieron su cariñoso consejo y ayuda de manera anónima.

Pero hay una faceta que es la que se me hace más patente cuando lo recuerdo (y es compartida por todos sus amigos): tenía un sentido del humor exquisito. Las reuniones de trabajo eran interrumpidas frecuentemente por bromas y carcajadas. Se trabajaba bajo gran tensión, pero en un ambiente muy alegre. En una oportunidad, un Director de una de las Escuelas de la Facultad hizo su cuenta de despedida, y luego de detallar todos los logros de su gestión, ofreció sus disculpas por las posibles ofensas infligidas durante su administración. Luego pidió a los presentes decirle si había algo que no le hubiera gustado de ella. Silencio, algo tenso. Juan, siendo el decano, pide la palabra y dice: "Bueno, de tu gestión la verdad que no tengo nada que objetar, y más bien al contrario... pero hay algo que no me gusta de ti". Todos los presentes se quedaron atónitos, el Director, algo turbado, dice, “¿Y qué sería?”. “¡Tus camisas!”, responde Juan, muerto de la risa, desatando la hilaridad de todos, y del director el que más. Así era Juan de Castro.

La última vez que lo ví, ya avanzada su enfermedad, y caminando y respirando apenas, lo encontré en Casa Central de la Universidad. "Haben sie gut geschlafen?” (¿ha dormido Ud. bien?), me preguntó con su característica risa. Siempre me saludaba así, 
pues me decía que esas eran las únicas palabras en alemán que conocía, y desde que retorné de mi doctorado en Alemania usó por siempre ese saludo. Después de una muy breve conversación, le pregunté qué hacía en la Universidad, y si no debía estar en reposo, preocupado por su evidente enfermedad. Me respondió: "Vine a agradecer al Rector, por el cariñoso trato de todo el personal del hospital de la Universidad, y por su gentileza de mediar para que el hospital no me cobrara nada"....se me quedó mirando algo socarrón y añadió..... “ ¡aunque igual no habría podido pagarle esa suma......!", terminó con su característica carcajada. Más serio, me habló de su amor por la Universidad, y de lo bien tratado que se había sentido toda la vida por ésta y sus autoridades. Este pequeño gesto refleja cómo era este hombre bueno. Se levantó de su lecho de enfermo, una de las últimas veces, para ir a agradecer la bondad de otros.

Ahora, sólo quiero hacer lo mismo, en nombre de todos quienes lo conocimos. Gracias Juan, por tu amistad, por tu cariñosa compañía, por ayudarnos a ser mejores personas, por tu fé, por dejarnos un recuerdo tan limpio, por tu sonrisa amplia y transparente, por tu risa fácil e inteligente, por tus libros, por tus clases, por tus grupos de estudio y trabajo, por creer en la Psicología como disciplina de lo humano. Gracias. Hasta siempre. 